\title{
"Settled Completely and Finally": A Japanese Perspective on the Repatriationism of Cultural Property
}

\section{Yoshiaki Sato*}

This article focuses on the Korean claim for repatriation of cultural property currently located in Japan. Through an analysis of the relevant rules of international law, it demonstrates the established norm that the predecessor state is not obliged to repatriate the cultural property acquired in and exported from the annexed territory. It further shows that, even if Japan had not annexed the Empire of Korea and just occupied it, the repatriationists' claim would not hold water, as the question has been conclusively settled by a bilateral agreement between Japan and the Republic of Korea. Considering that the parties to a settlement should refrain from subsequently relitigating the matter, the author concludes that cultural property, which can be a powerful ambassador for promoting mutual understanding, should be dealt with in the framework of forward-looking cooperation, including mutual loans and possibly the creation of a multinational museum.

\section{Keywords}

Repatriation, Cultural Property, Intertemporal Law, UNESCO Convention, Joseon Wangsil Uigwe

Let bygones be bygones.

Mao Tse-tung ${ }^{1}$

* Professor of Law at Seikei University, Japan. LL.B./LL.M./Ph.D. (Tokyo). ORCID: http://orcid.org/0000-0002-47383489. The author will appreciate the comments by Keisuke Mark Abe and Koji Ito. He may be contacted at: sato@law. seikei.ac.jp/Address: Faculty of Law, Seikei University, 3-3-1 Kichijoji-Kitamachi, Musashino, Tokyo 180-8633 Japan. DOI: http://dx.doi.org/10.14330/jeail.2017.10.1.10

1 P. Duus, Introduction: History Wars in Postwar East Asia, 1945-2014, in 'History Wars' and ReConciliation IN Japan and Korea: The Roles of Historians, Artists and Activists 1-4 (M. Lewis ed., 2017). 


\section{Introduction}

The relationship between Japan and the Republic of Korea ("ROK") $)^{2}$ continues to be in disarray. One of the main reasons is their different perspectives on the past history. In academia, thanks to the dispassionate evaluation of the merits and demerits of the Japanese administration of the annexed Korea, the distance between the views of the historians of the two countries appear to be closing. ${ }^{3}$ In contrast, the disparity between the popular sentiments seems to be widening. This is partly due to the school textbooks compiled by the Korean government which are criticized by historians, including those of Korea itself, for being full of unfounded and biased description. ${ }^{4}$ The populace of the ROK has been led to believe the distorted history as truth and has as a result internalized hatred against the Japanese. Korean politicians are often able to divert the people's attention from the political difficulty caused by scandals and to gather popular support by exploiting such hatred and instigating nationalistic hysteria. It is worth examining whether such 'government speech' is consistent with Article 20, paragraph 2 of the International Covenant on Civil and Political Rights, adopted on December 16, 1966, ${ }^{5}$ which obligates State Parties to put a ban on any advocacy of national hatred that constitutes incitement to hostility. ${ }^{6}$

The treatment of cultural property has been one of the major subjects of dispute in this part of the world. The Japanese have admired Korean artifacts since ancient times. E.g., the founders of the modern tea ceremony (chanoyu) in Japan in the middle of the sixteenth century appreciated Korean tea bowls very much. In fact, the use of Korean tea bowls symbolized the end of the old style of chanoyu known as "shoin no

2 This article would discuss the claims for expatriated cultural property by the ROK. The author would like to deal with the claims by the Democratic People's Republic of Korea on another occasion.

3 G. Akita \& B. Palmer, The Japanese Colonial Legacy in Korea 1910-1945: A New Perspective 11 (2015). (The authors point out that, thanks to the studies by Korean and American scholars examining a variety of developments in the Korean society during the Japanese administration, the historiography of Japan's rule of Korea is undergoing a gradual transformation).

4 Young Hoon Rhee, The Story of the Republic of KoreA 大韓民国の物語 77-8, 82-5, 121-2 \& 200 (Hiroki Nagashima trans., 2009) <available only in Japanese>. E.g., the description about the 'comfort women' in the textbook for high school students is said to be 'pure fabrication.' See Wansop Kim, Apology for the Pro-Japanese Koreans: The False ImAGE OF THE NATIONAL Heroes AND THE ReAlity OF THE EMPIRE OF JAPAN 親日派の弁明2: 英雄の虚像、日帝の実像 222 (2006) < available only in Japanese>. See also id. at 345, 354-5 \& 385.

5999 U.N.T.S. 14668 , at 172.

6 International Convention on the Elimination of All Forms of Racial Discrimination (660 U.N.T.S. 9464, at 212), art. 4. It condemns propaganda attempting to promote racial hatred and obligates the State Parties to declare an offence punishable by law all dissemination of ideas based on hatred. 
cha" and the beginning of the new style of chanoyu known as "wabicha." Because of the historical and aesthetic value of the Korean cultural objects, the Japanese collected them. It is likely that some Japanese, as well as "rich and urbane Korean colonial elite[s]," purchased things from 'locals' with dubious claims of ownership without scruple. ${ }^{8}$ Many Japanese, however, apparently did their best to preserve the cultural objects, observing the academic standard of those days. Prominent examples include the promulgation of the Act on Preservation of Historical Remains and Relics by the Government-General of Korea followed by the establishment of the Commission for Research of Historical Sites in 1916. This Act preceded the enactment of a similar statute in mainland Japan by three years.

The primary purpose of this research is to discuss various issues concerning international law with regard to the Korean claim for repatriation of cultural property currently located in Japan. It will demonstrate that the predecessor state is not obliged to repatriate the cultural property acquired in and exported from the annexed territory. It will also make it clear that, even if Japan had not annexed the Empire of Korea ("EOK") and just occupied it, the claim for the expatriated cultural property would not hold water, as the question has been settled by a bilateral agreement between Japan and the ROK. The examination of the matter must have been finished once the settlement by legal means was reached, because it would be counterproductive to leave leeway to revise the conditions of the settlement. Nonetheless, this article will go on to scrutinize the non-legal argument for the repatriation. It will attempt to refute the repatriationists' assertion based on the international tendency or various policy considerations. This paper is divided into five parts including a short Introduction and Conclusion. Part two will discuss international law. Part three will analyze international tendency. Part four will considers appropriate policies.

7 Nam-Lin Hur, Korean Tea Bowls (Kōrai Chawan) and Japanese Wabicha: A Story of Acculturation in Premodern Northeast Asia, 38 Korean Stud. 3 (2015).

8 Hyung-Il Pai, The Creation of National Treasures and Monuments: The 1916 Japanese Laws on the Preservation of Korean Remains and Relics and Their Colonial Legacies, 25 Korean Stud. 76 (2001). 


\section{International Law}

\section{A. Lack of Obligation to Repatriate Cultural Property Expatriated from an Annexed Territory}

Before the end of the Japanese administration of Korea in 1945, there was no rule of general international law which prohibited a state from acquiring or exporting cultural property originating in its annexed territory. The law of state succession did not obligate the predecessor State to repatriate such cultural property to the newly independent State, either. ${ }^{9}$ It is true that Article 15, paragraph 1 (e) of the Vienna Convention on Succession of States in respect of State Property, Archives and Debts, adopted on April 8, $1983^{10}$ stipulates that, when the successor State is a newly independent State, movable property, having belonged to the territory to which the succession of state relates and having become state property of the predecessor state during the period of dependence, shall pass to the successor state. However, this Convention has been ratified by only seven states, not including Japan or the $\mathrm{ROK}$, and has not entered into force. Its provision relating to the repatriation of the cultural property has therefore not yet been recognized as reflecting a binding rule of customary international law. ${ }^{11}$

There is a difference of opinion as to the validity of the Japan-Korea Treaty concluded on November 17, 1905, which made the EOK a protectorate of the Empire of Japan ("EOJ"). However, Japan and the ROK disagreed when they signed the Treaty on Basic Relations on June 22, 1965. ${ }^{12}$ Article 2 stipulates that all treaties concluded between the EOJ and the EOK on or before August 22, 1910, "are already null and void." [Emphasis added.] It is misleading to insist that "[ $t$ ]he validity of annexation-related treaties remain an important legal issue between Korea and Japan." ${ }^{, 13}$ For both countries, the question of the validity of those treaties has already become of little significance.

When considering the question of the validity of annexation-related treaties, one needs to bear in mind that their validity is to be determined by the authorities of the

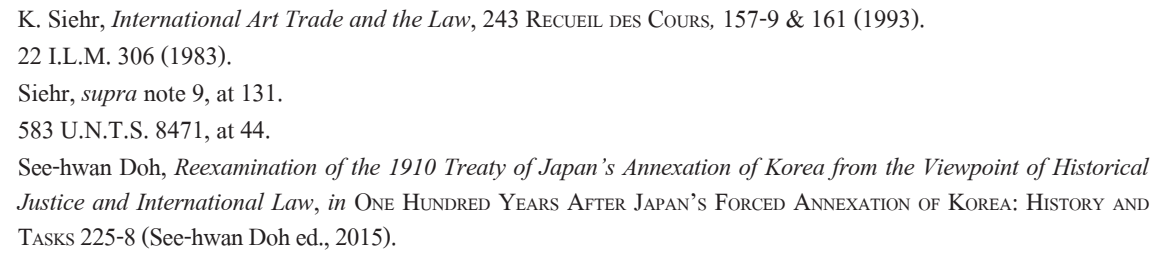


State Parties as well as those of other member States of the international community. Not only the Japanese authorities but also the majority of the Cabinet ministers of the EOK, including Ye Wanyong, then Minister of Education and later Prime Minister, ${ }^{14}$ acted on the premise that these treaties were valid. In addition, no third State considered these treaties to be defective. After the conclusion of the Treaty of 1905, e.g., all of the states closed their legations in Seoul. None that attended the Second Hague Peace Conference of 1907 accepted the private messengers of the Korean Emperor as formal envoys of the EOK, for they were not vested with capacity by the Governor-General of Korea according to the 1905 Treaty. ${ }^{15}$ It is not the nonauthoritative assessment of the situation of the signature by commentators, but the official recognition by the relevant governments of the day, that is dispositive. That the annexation-related treaties were not null and void $a b$ initio can be confirmed by the fact that no single state behaved on the assumption that the EOK continued to exist. ${ }^{16}$ The signatories of the San Francisco Peace Treaty were no exception. ${ }^{17}$

One needs to recall that the transportation of cultural property out of an annexed territory did not in itself depart from international law of those days, and that the transfer of cultural property was sometimes required in the daily administration. E.g., the Joseon Wangsil Uigwe, i.e., the Royal Protocols of the Joseon Dynasty, was transported to mainland Japan for the purpose of making a record of the funeral of King Emeritus Yi, which would be made reference to for preparing for the state funeral of King Yi. ${ }^{18}$ Unlike French troops' plunder of the sole and royal copy of Uigwe stored in Oegyujanggak (Royal Library out of Seoul) in 1866, all of the copies of Uigwe transported to mainland Japan were duplicated copies compiled for practical purposes. The Governor-General of Korea did not relocate the copies with no reproduction. ${ }^{19}$ It is reported that, between 1910 and 1945, some cultural objects

14 It will be interesting to compare the life of Ye with that of Feng Dao. Cf. Feng Dao and Wang Chao-ming 馮道と汪兆 銘, in COMPlete Works of ICHISADA MiYAZAKI 宮崎市定全集, (vol. 23) 145 (1993)<available only in Japanese>. (Feng Dao apologize that he was loyal to the nation rather than to the monarchs).

15 M. Seth, A Concise History of Modern Korea: From the Late Nineteenth Century to the Present (vol. 2) 38-9 (2d ed. 2016). After one of the envoys (Yi Wi-jong) gave a speech at the foreign press club in The Hague, "[m]uch of the press coverage of the Koreans came to sympathize with them." See Kyung-Moon Hwang, A History of Korea 134 (2d ed. 2017). Even though faced with such press coverage, none of the attendant states changed their attitude.

16 The British government was said to have made no protest against the EOJ-EOK annexation treaty of 1910. See L. McNair, The Law of Treaties 209 (1961).

17 Keun-Gwan Lee, Reassessing the Japanese Annexation of Korea from the Perspective of International Law: The Illegality of the Annexation and the "1965 Korea-Japan Claims Settlement Agreement," in Doh, supra note 13, at 25762.

18 NHK Syuzal-HAN, Joseon WANGSIL “UigWE”: ITS WANDERING FOR HUNDRED YeARS 朝鮮王朝「儀軌」: 百年の流転 103-11 \& 139-45 (2011), < available only in Japanese>

19 Id. at 136-9, 156-7, $167 \& 202$. 
were looted, sold and removed from Korea in contravention of domestic law. Such cases were handled in accordance with the civil or criminal law applicable to Korea. At all events, as more than 70 years have passed since the end of the Japanese administration, it seems fair to say that "the colonial and imperialistic past is barred by statutes of limitation and similar barriers, and its future is a matter of goodwill and policy." 20

\section{B. Settlement of Claim for Restitution of Cultural Property Expatriated from an Occupied Territory}

\section{Settlement by Bilateral Agreement}

If, arguendo, Japan had not annexed the EOK and just occupied Korea, it would be possible to argue that Japan breached international law by seizing and exporting cultural property. Article 46 of the Regulations concerning the Laws and Customs of War on Land ${ }^{21}$ stipulates that private property must be respected and cannot be confiscated. ${ }^{22}$ Article 53 of the Regulations provides that an army of occupation can only take possession of movable property belonging to the occupied state which may be used for military operations. Korea has not ratified the Convention, while Japan has. Nevertheless, these articles are thought to have codified the thenexisting rules of war. ${ }^{23}$ Paragraph 3 of the Protocol to the Hague Convention for the Protection of Cultural Property in the Event of Armed Conflict adopted on May 14, 1954 (hereinafter Hague Protocol of 1954), ${ }^{24}$ corroborates the obligation to repatriate the cultural property which has been illegally exported from an occupied territory. The exportation of seized cultural objects is most probably forbidden as well, for "if cultural property may not be seized, then a fortiori it may not be exported." ${ }^{25}$ Hence, but for the annexation, the Government-General of Korea must have violated the law by seizing and exporting the cultural objects most of which were owned by the EOK.

Even if Japan had breached the international obligations concerning cultural property and owed state responsibility, the Korean claims should be seen as already settled by a bilateral agreement. Japan and the ROK concluded the Agreement on

20 K. Siehr, Globalization and National Culture: Recent Trends toward a Liberal Exchange of Cultural Objects, 38 VAND. J. Transn'L L. 1071 (2005).

21 Annex to the Convention (IV) Respecting the Laws and Customs of War on Land adopted on Oct. 18, 1907. See ICRC, Treaties, State Parties and Commentaries, available at https://ihl-databases.icrc.org/ihl/INTRO/195 (last visited on Apr. 17, 2017).

22 Article 47 of the Regulations declares that pillage is formally forbidden.

23 J.-M. Henckaerts \& L. Doswald-Beck, Customary International Humanitarian Law (vol. 1) 133 (2005).

24249 U.N.T.S. 3511, at 216.

25 Henckaerts \& Doswald-Beck, supra note 23, at 136-7. 
the Settlement of the Problem concerning Property and Claims and the Economic Cooperation on June 22, 1965. ${ }^{26}$ Article 2, paragraph 1 of this Agreement proclaims that the problem concerning property or claims of the two countries and their nationals, including those provided for in Article IV, paragraph (a) of the Treaty of Peace with Japan signed on September $8,1951,{ }^{27}$ is "settled completely and finally." Japan agreed to supply the products of Japan and the services of the Japanese people gratis, the total value of which amounted to USD 300,000,000. Japan granted longterm and low-interest loans up to USD 200,000,000 to the ROK, as well. The amount of the grants and loans was almost twice as much as the fiscal budget of the ROK. The burden owed by Japan was so heavy that President of the ROK, Syngman Rhee, thought it inevitable that, if the approval of the United States were to be given, the Japanese would come to Korea to recover their property that had been left when they had returned home. ${ }^{28}$

By accepting this lump-sum agreement, the government of the ROK, representing the nation as a whole, relinquished the right of diplomatic protection against Japan and took over the responsibility to satisfy the claims of its nationals. ${ }^{29}$ According to Article 31, paragraph 3(b) of the Vienna Convention on the Law of Treaties adopted on May 23, 1969, ${ }^{30}$ the "subsequent practice in the application of the treaty" is required to be taken into account. The Korean government enacted a series of statutes that were aimed at settling the claims of its nationals. On February 19, 1966, the National Assembly of Korea enacted the Act on the Claims Fund Operation and Management (Law No. 1741). Article 1 of this Act ordains that the Claims Fund should be spent for the autonomous and balanced development of the national economy. At the same time, Article 5, paragraph 1 stipulates that the private claims owned by Korean nationals that arose before August 15, 1945, shall be compensated from the Claims Fund established by this Act. ${ }^{31}$ These statutory provisions substantiate the interpretation of the Agreement of 1965 that the Korean government is responsible to satisfy the claims of its nationals.

It is worth noting that, on April 27, 2007, the Supreme Court of Japan delivered to the victims. See Lee, supra note 17, at 269.

301155 U.N.T.S. 18232 , at 331.

31 The ROK enacted in succession the Act on the Declaration of the Private Claims against Japan and the Japanese Nationals (Law No. 2287) on January 19, 1971, and the Act on the Compensation for the Private Claims against Japan and the Japanese Nationals (Law No. 2685) on December 21, 1974. 
two judgments regarding the claims of the Chinese nationals concerning the acts of Japan and a Japanese company during the Asia-Pacific War (WWII). ${ }^{32}$ The Supreme Court dismissed the plaintiffs' claims, stating that their procedural rights to bring cases in court regarding the defendants' wartime activities had ceased to exist in accordance with Paragraph 5 of the Japan-People's Republic of China ("PRC") Joint Communiqué of September 29, 1972. ${ }^{33}$ This paragraph declares that, "in the interest of the friendship between the Chinese and the Japanese peoples, [the Chinese government] renounces its demand for war reparation from Japan." The Supreme Court elucidated that the Joint Communique should be regarded as part of the framework of the post-war settlement established by the Treaty of Peace with Japan. ${ }^{34}$ It went on to state that the purpose of a peace treaty would not be served if the nationals of one party were allowed to retain the right to file suits in the national courts of the other, because that would give rise to a flood of litigation. ${ }^{35}$ This logic may well be applied to the interpretation of the Japan-ROK Agreement of 1965.

In addition to the Agreement on the Settlement of the Problem concerning Property and Claims, Japan and the ROK concluded the Agreement on the Art Objects and Cultural Co-operation. ${ }^{36}$ Article 2 of this Agreement obligates Japan to turn over the art objects enumerated in the Annex to the government of the ROK. In compliance with this Annex, Japan handed over 852 books, 20 examples of communication devices and materials, 176 ceramics, and 434 items of other works of art. Cultural property held by private owners was not enumerated in this Annex. In the Agreed Minutes regarding the Agreement on the Art Objects and Cultural Cooperation, ${ }^{37}$ the Japanese government stated that the voluntary donation of art objects originating in Korea to the Korean side by the Japanese owners is 'commendable.'

It would be interesting to compare this Agreement with other treaties of the similar function. Article 16 of the Treaty of Good Neighbors, Partners and Cooperation between the Federal Republic of Germany and the Union of Soviet Socialist Republics signed on November 9, 1990 (hereinafter Germany-USSR Treaty), e.g., stipulates that the Contracting Parties promised that "lost or unlawfully taken

32 See Judgment in the Hiroshima Case, available at http://www.courts.go.jp/app/files/hanrei_jp/580/034580_hanrei.pdf; Judgment in the Tokyo Case, available at http://www.courts.go.jp/app/files/hanrei_jp/591/034591_hanrei.pdf (all last visited on Apr. 17, 2017). For the summaries of these cases, see 51 JAPANESE Y.B. INT'L L. 518 (2008).

33 Joint Communiqué of the Government of Japan and the Government of the People's Republic of China (Sept. 29, 1972), available at http://www.ioc.u-tokyo.ac.jp/ worldjpn/documents/texts/docs/19720929.D1E.html (last visited on Apr. 17, 2017).

34 Judgment in the Hiroshima Case, supra note 32 , at 15-8.

35 Id. at 11-2.

36584 U.N.T.S. 8475, at 112.

37 Id. at 144 . 
cultural treasures, which are situated within their territory, shall be repatriated to the owner or its legal successor." 38 Instead of establishing a principle of repatriation like the Germany-USSR Treaty, the Japan-ROK Agreement appends a limitative listing, specifying the cultural property to be delivered to the ROK. This was part of the package deal consisting of more than 25 agreements concluded on June 22, 1965.

\section{Lack of Peremptory Norm that Supersedes Bilateral Agreement for Settlement} Lack of Obligation under General International Law to Repatriate Cultural Property There is no rule of general international law that obligates a state that possesses cultural objects created in the territory of another state to repatriate them, regardless of the timing or ways of acquisition or exportation. Three multilateral conventions may be relevant: the Hague Protocol of 1954, the UNESCO Convention on the Means of Prohibiting and Preventing the Illicit Import, Export and Transfer of Ownership of Cultural Property adopted on November 14, 1970 (hereinafter UNESCO Convention), ${ }^{39}$ and the UNIDROIT Convention on Stolen or Illegally Exported Cultural Objects adopted on June 24, 1995 (hereinafter UNIDROIT Convention). ${ }^{40}$

Paragraph 3 of the Hague Protocol of 1954 stipulates that Contracting Parties undertake to return, at the close of hostilities, to the competent authorities of the territory previously occupied, cultural property which has been exported to its territory. It also prohibits retaining war reparations. It is of interest that, during the diplomatic conference for adopting The Hague Protocol of 1954, Norway proposed that a clause be inserted to the effect that "restitution cannot ... be required later than twenty years after the object has got into the hands of the present holder, this holder having acted in good faith in acquiring it." The Norwegian proposal was not adopted. ${ }^{41}$ However, Japan has attached a declaration to the effect that it will fulfill its obligation under Paragraph 3 in a manner consistent with its domestic laws including the Civil Code. ${ }^{42}$ Although Japan has ratified this Protocol, the ROK has not, so it cannot be applied between Japan and the ROK as a treaty. It is also difficult to regard this Protocol as reflecting the rule of customary international law, for the

\footnotetext{
1707 U.N.T.S. 29524, at 407.

823 U.N.T.S. 11806 , at 231.

2421 U.N.T.S. 43718 , at 457.

41 J. Toman, The Protection of Cultural Property in the Event of Armed Conflict: Commentary on the Convention for the Protection of Cultural Property in the Event of Armed Conflict and Its Protocol, Signed on 14 May, 1954 in the Hague, and on Other Instruments of International Law concerning Such Protection 345 (1996).

42 See the full text of Protocol to the Convention for the Protection of Cultural Property in the Event of Armed Conflict 1954, available at http://portal.unesco.org/en/ev.php-URL_ID=15391\&URL_DO=DO_TOPIC\&URL_ SECTION=201.html\#STATE_PARTIES (last visited on Apr. 17, 2017).
} 
Protocol has been ratified by just 105 States so far, with major powers such as the UK and the US failing to take necessary steps.

In contrast, the UNESCO Convention has been ratified by 131 States, including both source countries and countries of destination. ${ }^{43}$ Japan ratified it in September 2002, while the ROK did it on February 14, 1983. Unlike the UNIDROIT Convention, the UNESCO Convention does not set any time limit for claiming restitution, ${ }^{44}$ leaving the Contracting Parties to apply their own national law. The UK has declared that, pursuant to Article 7 (b)(ii), it will apply its existing rules on limitation to claims for recovery. Article 7 of the UNESCO Convention deliberately denies the retroactive effect, by limiting its application to situations occurred after its entry into force in the States concerned. It confirms the point by the declaration of Chile and the US that the Convention shall not have any retroactive force. Therefore, the UNESCO Convention is not applicable to the cultural property expatriated from Korea during the Japanese administration.

Denial of retroactive application was well recognized in the Island of Palmas Case by the Permanent Court of Arbitration ("PCA"). In this case, the PCA awarded: "A juridical fact must be appreciated in the light of law contemporary with it, and not of the law in force at the time when a dispute in regard to it arises or falls to be settled. ${ }^{45}$ It is also codified in Article 28 of the Vienna Convention on the Law of Treaties. The principle is generally recognized and called 'intertemporal' law. As for the Parthenon Marbles (Elgin Marbles) owned by the British Museum, it is sometimes argued that "an act of theft of cultural treasures 200 years ago is equally reprehensible as the same act today." 46 Such an argument seems ludicrous on its face, because the removal of the Parthenon Marbles was not an act of theft under the applicable law of the time, i.e. the law of the Ottoman Empire. A 'trans-temporal' approach is proposed for assessing events of the colonial era, which refers to international law "at that time or of today." 47 This 'new' approach offers no criterion

43 These days, more reference is made to source community than to source country. See, e.g., U. Gößwald, ICOM Statement on Reclaiming Cultural Property, 241-242 Museum InT'L 87 (2009).

44 See UNESCO Information Note: Complementarity Between, and Functioning of the 1970 UNESCO Convention on the Means of Prohibiting and Preventing the Illicit Import, Export and Transfer of Ownership of Cultural Property and the 1995 UNIDROIT Convention on Stolen or Illegally Exported Cultural Objects, June 16, 2005. See Doc. CLT-2005/ Conf $/ 803 / 2$, at $4-5$.

45 Island of Palmas Case (Neth. v. U.S.), 2 R.I.A.A. 845 (Perm. Ct. Arb. 1928), available at http://legal.un.org/riaa/ cases/vol_II/829-871.pdf (last visited on Apr. 17, 2017).

46 Speech by Colonel Matthew Bogdanos, cited in Resolution for Parthenon Marbles Return Proposed at UNESCO Conference, Mar. 22, 2008, hellotia.com, reprinted in Press Review of the Athens International Conference on the Return of Cultural Property to Its Country of Origin, Athens, Mar. 17-18 2008, at 38, available at http://www.unesco. org/culture/laws/pdf/Revuedepresse_Athenes.pdf (last visited on Apr. 17, 2017).

47 Lee, supra note 17, at 270-1 (confessing that it is not easy to clarify this approach and apply it to actual events). 
that enables the harmonization of the norms of the past era and those of today, leaving each actor to "pick and choose" the norms of his/her preference and creating chaos.

Article 4 (a), (d) and (e) of the UNESCO Convention recognize that not only the cultural property created by the individuals of the state concerned, as well as that of importance to the state concerned created within its territory by foreign nationals or stateless persons residing therein, but also the cultural property which has been the subject of a freely agreed exchange or which has been received as a gift or purchased legally with the consent of the competent authorities of the country of origin, forms part of the cultural heritage of each State. There is no order of priorities among the States claiming a particular piece of cultural property as their cultural heritage, so that there is no obligation for one of the qualified States to return it to another. The right and responsibility over cultural heritage should belong, in the first place, to the cultural community that has generated it. However, subsequently, it may move to the state which takes care of it. ${ }^{48}$

Unlike the UNESCO Convention, the UNIDROIT Convention has been ratified by only 37 States. Neither Japan nor the ROK has ratified it. The UNIDROIT Convention adopts residual rules of temporary limitation. Article 3, paragraph 3 stipulates that any claim for restitution shall be brought within three years from the time when the claimant comes to know the location of the cultural object and the identity of its possessor, and in any case within 50 years from the time of the theft. ${ }^{49}$ Article 3, paragraph 5 allows State Parties to derogate from the absolute time limitation stipulated in paragraph 3 by declaring that a claim is subject to a time limitation of 75 years or longer as provided in their law..$^{50}$ For the time being, the PRC, Ecuador, Guatemala and the Netherlands have accepted a time limitation of 75 years for submission of claims for the repatriation of cultural objects. The PRC also takes the position that it reserves the right to extend this time period. ${ }^{51}$ Moreover, Article 9, paragraph 1 of the UNIDROIT Convention allows Contracting States to

[Emphasis added]

48 Preamble to the Nara Document on Authenticity (1994), at 1, 8 , available at http://www.icomos.org/charters/ nara-e.pdf (last visited on Apr. 17, 2017).

49 The following paragraph establishes a special regime for a claim for restitution of "a cultural object forming an integral part of an identified monument or archaeological site, or belonging to a public collection." Such a claim shall be subject only to the relative time limitation, not to the absolute ones.

50 When a State Party adopts such a longer time limitation, it is required to apply it also to the claims regulated by paragraph 4 described above.

51 UNIDROIT Convention art. 3 (5), available at http://www.unidroit.org/status-cp/281-instruments/culturalproperty/cultural-property-convention-1995/status/1480-1995-article-3-5 (last visited on Apr. 17, 2017). 
apply any rule more favorable to repatriation than provided by this Convention. ${ }^{52}$ Because of such provisions in favor of the source countries, incorporating 'too ambitious' elements, ${ }^{53}$ none of the countries of destination has ratified it.

The Operational Guidelines for the Implementation of the UNESCO Convention indicate that the UNESCO Convention has an important complementary relationship with the UNIDROIT Convention. ${ }^{54}$ Furthermore, Annex 6 to the Guidelines encourages the State Parties of the UNESCO Convention to become parties to the UNIDROIT Convention. ${ }^{55}$ It seems inappropriate for the UNESCO to endorse a treaty which has been adopted by another international organization unless the majority of its member States accept it. What the UNESCO should do is to seek revision of the UNIDROIT Convention to make it better balanced and more widely acceptable.

At any rate, Article 10, paragraphs 1 and 2 of the UNIDROIT Convention deny the retroactive effect. A saving clause has been subjoined to paragraph 3, which makes it clear that this Convention neither legitimizes any illegal transaction that has taken place before the entry into force of this Convention, nor limits any right of a State to seek available remedies outside the framework of this Convention for the restitution of a cultural object stolen or illegally exported before the entry into force of this Convention. Such a disclaimer cannot demonstrate the existence of the said right by itself. As mentioned above, there is no right under the general international law to claim the repatriation of cultural property, so that this right is a purely conventional one.

52 Although the interest of the good faith purchaser of cultural property and that of the dispossessed owner are said to be equally legitimate, the drafters assert that there can be no possibility for lowering the level of protection already granted to the latter. See UNIDROIT Convention on Stolen or Illegally Exported Cultural Objects: Explanatory Report, 6 UNIF. L. REv. 476-500 (2001), available at http://www.unidroit.org/english/conventions/1995culturalproperty/1995culturalpr operty-explanatoryreport-e.pdf (last visited on Apr. 17, 2017).

53 Siehr, supra note 20, at 1084.

54 See Operational Guidelines for the Implementation of the Convention on the Means of Prohibiting and Preventing the Illicit Import, Export and Transfer of Ownership of Cultural Property (hereinafter Operational Guidelines), May 2015, at 14, ๆ 52, available at http://www.unesco.org/fileadmin/MULTIMEDIA/HQ/CLT/pdf/OPERATIONAL_ GUIDELINES_EN_FINAL.pdf (last visited on Apr. 17, 2017). This document encourages the States Parties of the UNESCO Convention to incorporate into bilateral or regional agreements the highest level of protection developed in the Convention as well as in the UNIDROIT Convention. See id. at $24,113$.

55 See Annex to Operational Guidelines, at 47-8. The UNESCO's International Code of Ethics for Dealers in Cultural Property also makes express reference to Article 4 of the UNIDROIT Convention. See UNESCO's International Code of Ethics for Dealers in Cultural Property, Nov. 1999, Doc. CLT/CH/INS-06/25, available at http://portal.unesco.org/ culture/en/ev.php-URL_ID=13095\&URL_DO=DO_TOPIC\&URL_SECTION=201.html (last visited on Apr. 17, 2017). 
Lack of Prohibition of Settlement of the Claims of Victims of Illegal Acts against Humanity by Agreement between Relevant Governments

Only after several decades, the ROK government started to claim the illegal acts against humanity committed by the Japanese authority, such as those concerning the 'comfort women,' the abandoned Koreans in Sakhalin and the victims of the atomic bombs, which allegedly could not have been settled by the 1965 Agreement on the Settlement of the Problem concerning Property and Claims (hereinafter 1965 Agreement on Property Claims). ${ }^{56}$ The ROK government now maintains that claims from the breach of peremptory norms in international law cannot be disposed of by the agreement of relevant governments. ${ }^{57}$ As the judgment of 2007 by the Supreme Court of Japan points out, however, the state's sovereign power includes the authority to deal with every kind of claims of its nationals. ${ }^{58}$ No exception has been recognized to the exercise of this power. The terms of a treaty must be interpreted in accordance with their ordinary meaning, in their context and in the light of the object and purpose of the treaty. ${ }^{59}$ Excluding certain categories of claims from the subject of the settlement is contrary to the ordinary meaning of the 1965 Agreement on Property Claims, whose object was to settle all of the problems completely. [Emphasis added] If the Korean nationals are free to pursue their claims in court, the object of ensuring the finality of the settlement cannot be fulfilled. If the argument about the exceptions with respect to acts against humanity were to be endorsed, the 1965 Agreement on Property Claims must be seen as null and void ab initio, because the two governments must have acted ultra vires when they concluded the Agreement. If this were the case, the ROK government would be required to refund the amount of the grants and the benefits it enjoyed from the reduction of the interest of the debts. It is also notable that the ROK government itself does not insist that the repatriation of cultural property should be out of the scope of the Basic Treaty of 1965.

\footnotetext{
56 See Office for Government Policy Coordination, Press Material concerning the Meeting of the Government-Civilian Joint Committee on Preparing Measures Following the Disclosure of Documents of the Korea-Japan Normalization Accord 韓日会談文書公開後続対策関連民官共同委員会開催 (Aug. 26, 2005), available at http://www.nichibenren.or.jp/ library/ja/kokusai/humanrights_library/sengohosho/sonota_01.pdf (last visited on Apr. 17, 2017). [Emphasis added]

57 Lee, supra note 17 , at 267.

58 Judgment in the Hiroshima Case, supra note 32, at 12.

59 Vienna Convention on the Law of Treaties, art. $31, \uparrow 1$.
} 


\section{International Tendency}

In the Conclusions of the Athens International Conference on the Return of Cultural Objects to Their Countries of Origin adopted in March 2008, participants declared that "a clear tendency towards the return of cultural objects to their countries of origin ha[d] been developed on legal, social and ethical grounds. ${ }^{\circ 60}$ However, the reality seems opposite. With respect to good faith purchases of cultural property, e.g., no such trend can be observed. Rather, there exits "a trend for liberalizing nationalistic cultural policy." " It is true that, since 1972, the UN General Assembly adopted has more than 25 resolutions on "return or restitution of cultural property to the source countries." ${ }^{62}$ The very fact that similar resolutions have been adopted so many times is a proof that there is no substantial change in the attitude of the related countries. Source countries have held a number of conferences for promoting the repatriation of cultural property. E.g., a conference held in April 2010 adopted the Cairo Communiqué. It declared that: "Ownership of cultural heritage by the country of origin does not expire, nor does it face prescription." ${ }^{\prime 63}$ This statement is incompatible with Article 4 of the UNESCO Convention mentioned above. The UN General Assembly never took note of the Cairo Communiqué, ${ }^{64}$ although it did take note of various declarations of other international forums, including the Declaration of the International Forum on the Return of Cultural Property (Seoul Declaration) adopted on July 19, 2011 . $^{65}$

Extrajudicial mutually beneficial repatriation agreements between museums owing cultural property and source countries are said likely to become "the new

60 See the full text of Conclusions of the Athens International Conference on the Return of Cultural Objects to Their Countries of Origin, available at http://www.unesco.org/culture/laws/pdf/Conclusions_Athens_en.pdf (last visited on Apr. 17, 2017). This statement declared that the "return of cultural objects is directly linked to the rights of humanity (preservation of cultural identity and preservation of world heritage)." It offers no answer to questions such as why the repatriation of cultural objects is linked to the preservation of world heritage, and why the preservation of cultural identity should be given priority over that of world heritage.

61 Siehr, supra note 20, at 1095-6.

62 G.A. Res. 70/76, U.N. Doc. A/RES/70/76 (Dec. 9, 2015).

63 Cairo Communiqué on International Cooperation for the Protection and Repatriation of Cultural Heritage, June 30, 2010, at 1, available at http://www.sca-egypt.org/eng/pdfs/RST_ICHC_SA\%20Communique_2010-08-20.pdf (last visited on Apr. 17, 2017). Whereas the ROK participated in the conference, not only countries of destination, but also many source countries such as Ethiopia, Ghana and Mali did not. This Communiqué advocated for the establishment of a procedure, whereby cases involving cultural objects could be heard at the ICJ. See id. at 5.

64 G.A. Res. 70/76, supra note 62, ๆ 7.

65 See the full text of the Seoul Declaration, available at http://www.unesco.org/new/fileadmin/MULTIMEDIA/HQ/ CLT/pdf/seoul_declaration_2011.pdf(last visited on Apr. 17, 2017). 
protocol for resolving cultural property disputes." 66 The possessors, however, usually donate their cultural property only when they have finished making its reproduction. E.g., the University of Tokyo donated 47 volumes of the Joseon Wangjo Sillok (Annals of the Joseon Dynasty), to Seoul National University, after making the digitalized copies and enabling the public to access these copies on its website. ${ }^{67}$ It is disheartening to note that, following this transfer of the Sillok, Korean activists organized a non-governmental organization for repatriating the Uigwe owned by the Japanese government.

The Japanese government is one of the most conscientious possessors that have turned over its cultural property to the source countries without any condition. When it agreed to hand over the Uigwe to Korea in 2011, the Japanese government was in the process of making its duplication. It seems imprudent for Japan to have taken such action, knowing that Korean activists would propagate a misleading impression that the Uigwe had been 'illicitly trafficked' and returned "as a token of an apology for colonization." 68 The activists argued: "The case of the Uigwe represents how the return of cultural properties can act as a means of reconciliation in political and cultural disputes between countries. ${ }^{" 69}$ However, there is no indication of reconciliation on the side of Korea. The Koreans expressed their intention to pursue return of at least 140,000 items scattered all over the world..$^{70}$ Meanwhile, more and more possessors have decided to loan their cultural property for certain period of time while retaining their ownership. Almost all of the agreements reached so far have been based on the voluntary pledges, not on lex ferenda.

The inconsistent stand of the Korean government is baffling in that it claims the repatriation of cultural property exported hundreds of years ago while neglecting to perform clear and present legal duties. In 1995, the Korean government suddenly designated three copies of the Large Prajnaparamita, printed in the eleventh century,

66 S. Falkoff, Mutually-Beneficial Repatriation Agreements: Returning Cultural Patrimony, Perpetuating the Illicit Antiquities Market, 16 J. L. \& PoL'y 265-8 (2007).

67 See the digitalized image of the Sillok, available at http://rarebook.dl.itc.u-tokyo.ac.jp/jitsuroku/korean.html (last visited on Apr. 17, 2017).

68 See Summary Report of the 2011 International Forum on the Return of Cultural Property: Strategies to Build the International Network for the Return of Cultural Property (speech by Hye Moon), available at http://www.unesco.org/ new/fileadmin/MULTIMEDIA/HQ/CLT/pdf/Seoul_2011_Summary_Report.pdf(last visited on Apr. 17, 2017).

69 Id. [Emphasis added]

70 Id. (remarks by Bonghyun Kim). Surprisingly, one commentator asserts that a sincere apology by Japan "would lead to more concrete ways of resolving the issue, such as actual physical returns of some of the Korean artifacts remaining in Japan." See Melissa Young-Jae Koo, Reparation of Korean Cultural Property Looted by Japan: Can a Sincere Apology Resolve the Centuries-Old Korea/Japan Disputes?, 16 CARDOZo J. Conflict Resol. 650 (2015). It is not likely that Koreans would be satisfied with return of some of their artifacts. The only way of resolving the issue must be renouncement of repatriationism. 
as national treasures. It is likely that they are the ones that had been stolen by a group of Korean thieves from a temple in Japan in the previous year. ${ }^{71}$ When the Japanese government requested the Korean government to check the identity of the copies, the Korean government refused.

The similar situation occurred in 2012 when three Koreans stole two Bodhisattva statues from a shrine and a temple in Japan. According to Article 7(b)(ii) of the UNESCO Convention, Korea is obligated to make restitution immediately. An ethical nation would keep its commitment embodied in the provisions of agreements. In 2017, however, a Korean district court ordered the Korean government to turn over one of the statues to a Korean temple, on the grounds that the statue had once belonged to that temple and had been transferred to the Japanese temple through a non-ordinary process. ${ }^{72}$ The Korean government had published a report in 2014 that it could not reach a definitive conclusion whether the statue had been taken to Japan by plunderers, though the answer was probably 'yes. ${ }^{73}$ It seems unfair for the court to shift the burden of proof from the claimant whose relationship with the original possessor is not obvious to the most recent owner who took care of the objects for more than several hundred years.

This unfortunate judicial decision discourages cultural exchange between Japan and the ROK. E.g., a project for an exhibition of Paekche jointly prepared by Japanese and Korean museums failed because of the Japanese organizers' fear that, once they loan the statues of Buddha to the Korean museum, the Korean court might enjoin their return after the exhibition. ${ }^{74}$ Similarly, Mexico was strongly criticized when it refused to make restitution of an ancient Aztec codex, known as the Aubin Tonalamatl. The codex was stolen by a Mexican from the Bibliothèque Nationale in Paris in 1982 and 'donated' to the Instituto Nacional de Antropología e Historia in

71 Tomoko Kanno, Pursuing the Korean Business of Theft and Black-Market Dealing of Artifacts: The Fate of THE TARgeted JAPANESE NATIONAL TREASURES 韓国窃盗ビジネスを追え: 狙われる日本の国宝 41-2, 54-7, 157 \& 159-61 (2012). <available only in Japanese>

72 Toru Higashioka, Local Court Rules Buddhist Statue Belongs to South Korea, not Japan, Asahi Shimbun DaILy, Jan. 26, 2017, available at http://www.asahi.com/ajw/articles/AJ201701260049.html (last visited on Apr. 17, 2017).

73 Sang-hun Choe, South Korea Can Keep Buddhist Statue Stolen from Japan, Court Says, N. Y. Times, Jan. 26, 2017, available at https://www.nytimes.com/2017/01/26/world/asia/south-korea-japan-buddha-statue.html?_r=0 (last visited on Apr. 17, 2017).

74 Kaoru Tezuka, On the Location of Cultural Property: Who Owns History? 文化財の帰趨をめぐって: 歴史を所有 するのは誰か, 56 HoKKAI GAKUEN U. J. HUMANITIES 北海学園大学人文論集 83 (2014)<available only in Japanese>. For resolving obstacles to the exchange of cultural property, a committee of the International Law Association has proposed a "Draft Convention on Immunity from Suit and Seizure for Cultural Objects Temporary Abroad for Cultural, Educational or Scientific Purposes," available at http://www.ila-hq.org/en/committees/index.cfm/cid/13 (last visited on Apr. 17, 2017). 
Mexico City. ${ }^{75}$ Such disorderly 'repatriation' should not be tolerated because it would encourage resort to self-help. ${ }^{76}$ Even if there exists an international tendency to repatriate cultural property by means of illegal acts, it cannot be recognized as a legitimate justification for non-compliance with law.

\section{Policy Considerations}

\section{A. Prudence in Prohibition of a Settled or Belated Claim}

Concluding a treaty which settles all of the claims relating to war and the administration of an annexed territory is an expression of wisdom coming from history. If one of the parties to a dispute is allowed to bring up historical claims repeatedly, a stable peace cannot be established. In addition, raising claims whose causes rest on events in the distant past is usually counterproductive. The prohibition of bringing up a settled or belated claim is incorporated in most peace treaties and agreements between predecessor States and newly independent States, including the Japan-ROK Basic Treaty of 1965. In order to break a vicious circle of vengeance, countries have recognized such rules as statutes of limitations and acquisitive prescription. ${ }^{77}$ These rules are key indicators of a society that endeavors to establish legal stability. It seems, however, that the people challenging the status quo in East Asia are becoming more assertive in claiming the return of cultural property as symbols of their glorious past, relying on reactionary rhetoric similar to irredentism. ${ }^{78}$ The responsible governments are expected to educate the general public to abide by the rules of positive law and refrain from recourse to self-help.

75 France was reported to be negotiating for a permanent loan with occasional joint exhibitions in European museums. See INAH to Keep Codex Stolen from French National Library, Feb. 28, 2009, available at http://mexiconationalmuseuma nthropology.blogspot.jp/2009/02/inah-and-stolen-maya-codex-from-french.html (last visited on Apr. 17, 2017).

76 Siehr, supra note 9, at 161.

77 In 2016, the Constitutional Court of the ROK upheld the provision concerning acquisitive prescription as constitutional, for it contributes to legal stability. See The Korean Constitutional Court: Registration of Rights and Acquisitive Prescription Is Necessary for the Stability of Legal Order 韓国憲法裁判所: 登記取得時効制は法秩序安定 [の]ために必要 , Mar. 4, 2016, available at http://www.e-profession.net/asiken/archives/5641 (last visited on Apr. 17, 2017). <available only in Japanese > Article 249, paragraph 4 of the Criminal Code of the ROK sets forth a statute of limitations of five years for the crime of acquiring stolen objects. It is reported that thieves specializing in cultural property usually wait for five years before selling the stolen objects. See KANNO, supra note 71, at 90, 108, 134, 136 \& 158.

78 The experience that a Korean state dominated large areas of Manchuria in the tenth century "still encourages many Korean nationalists to lay sovereign claim to large swatches of what is now northeastern China." See B. Cumings, Korea's Place In the Sun 39 (2005). 


\section{B. Acknowledgment of History As Is}

It is a historical fact that many Korean Buddhist temples had been in ruin when the Japanese discovered their cultural value at the beginning of the twentieth century. When Seong-gye Yi, also known as Taejo of Joseon, overturned the Goryeo Dynasty and founded the Joseon Dynasty at the end of the fourteenth century, his chief of staff dismissed Buddhism which had been protected by Goryeo kings and chose to propagate Confucianism. ${ }^{79}$ It is also undisputed that the Japanese, under the auspice of the Government-General of Korea, endeavored to protect cultural property originating in Korea. The Japanese institutions preserved the cultural objects with minute attention when the Korean people did not attach importance to their own heritage. The Japanese efforts have contributed to save the cultural property that is indispensable for understanding the history of Korea. The dispersion of the Japanese collection of the cultural property originating in Korea will be a serious loss of human knowledge. Later generations can learn lessons from it only by acknowledging history.

One commentator suggests that the just outcome can be reached by applying John Rawls's theory of justice. Specifically, it is argued that the location of cultural property should be determined according to the intention of the original creators. ${ }^{80}$ It is not self-explanatory, however, that the intention of the creators should be regarded as the supreme standard of justice derived from the 'original position.' According to Rawls, the 'original position' itself is not a goal to be realized but a "purely hypothetical situation characterized so as to lead to a certain conception of justice." ${ }^{, 1}$ Negation of history in toto cannot be justified by Rawls. As director of the Metropolitan Museum of Art in New York City asked, "history is unfair, but it always has been. Must every historical cycle be undone?" 82 Most probably the answer is 'no.' It would be anomalous to allocate every art object retroactively to the nation of its origin. ${ }^{83}$

79 One of the justifications for the overthrow of the previous regime was that the government was given over to corrupt religious practices. See F. Starr, Korean Buddhism: History-Condition-Art 22 (1918).

80 D. Fincham, The Parthenon Sculptures and Cultural Justice, 23 Fordham Intell. Prop. Media \& Ent. L. J. 984-7 (2013).

81 J. Rawls, A Theory of Justice 11 (1999).

82 A. Riding, Are Finders Keepers?, N.Y. Times, Mar. 12, 1995, at 3, available at http://www.nytimes.com/1995/ 03/12/weekinreview/the-world-are-finders-keepers.html (last visited on Apr. 17, 2017).

83 Siehr, supra note 9, at 242. 


\section{Establishing One's Identity Not Limited to Group Identity}

Cultural property is often associated with people's identity. The UNESCO often emphasizes such perception. The UNESCO Universal Declaration on Cultural Diversity adopted on November 2, 2001 points out that: "Culture is at the heart of contemporary debates about identity." ${ }^{84}$ The UNESCO also states that cultural objects have become important repositories of cultural identity and collective memory. ${ }^{85}$ Accordingly, the UNESCO expresses its wish to transmit heritage to future generations whose identities might be shaped by contact with the heritage. ${ }^{86}$ It recommends that education and awareness raising measures should be used to help local communities and the public in general to appreciate the cultural heritage's relation to the cultural identity. ${ }^{87}$ International forums have expressed the similar understanding. Seoul Declaration, e.g., observes that the international cooperation for the repatriation of cultural property constitutes a crucial means to restore national identity. ${ }^{88}$

It must be questioned, however, whether national identity exists prior to the repatriation of cultural property or it is to be constructed only after the acquisition of such property. In fact, a Korean journalist in the protectorate period "connected the country's imminent danger to the people's lack of nationalistic consciousness." 89 So-called cultural identity may be a myth constructed by some politically motivated propaganda. What is necessary is a skeptical attitude toward the discourse on identity based on a sense of belonging to a group sharing common history. Instead of emphasizing the collective dimension of individual identity and essentializing group identity, such discourse should bring the personal dimension and individual autonomy in focus. ${ }^{90}$ Identity can then be based on constitutional values, such as human rights, democracy, and the rule of law. The mandate of the Korean government as well as the UNESCO should be the promotion of concepts such as

84 UNESCO Universal Declaration on Cultural Diversity, pmbl., available at http://portal.unesco.org/en/ev.phpURL_ID=13179\&URL_DO=DO_TOPIC\&URL_SECTION=201.html (last visited on Apr. 17, 2017).

85 UNESCO, Our Creative Diversity: Report of the World Commission on Cultural and Development 201 (1995), available at $\mathrm{http} / /$ unesdoc.unesco.org/images/0010/001055/105586e.pdf (last visited on Apr. 17, 2017). See also id. at 9 (It points out that tensions over scarce resources push people into the narrow walls of group identity, feeding a new tide of confrontations between ethnic and national communities).

86 UNESCO, 37 C/4: Medium-Term Strategy 2014-2021 (2014), at 24, - 66, available at http://unesdoc.unesco.org/ images/0022/002278/227860e.pdf (last visited on Apr. 17, 2017). See also id. at 25, 99 (declaring that the pillage and illicit trafficking of cultural property violate the expression of a community's cultural identity).

87 Operational Guidelines, at 14, 92.

88 Seoul Declaration 2011.

89 HwaNG, supra note 15, at 133. [Emphasis added]

90 P. Nanz, Europolis: Constitutional Patriotism beyond the Nation-State 57-61 (2006). 
'constitutional patriotism.',

It may also to be questioned "whether today's governments are legitimate heirs of ancient civilizations or whether such antiquities belong to all mankind." Even if cultural identity is an indispensable element of people's identity, no reason is articulated why the location of cultural property must be related with cultural identity. Although the misrepresentation of the origin of cultural property amounts to the denial of recognition of other people's identity, repatriationism has nothing to do with cultural identity. A Korean historian rightly points out that a characteristic of the pre-modern society is the dominance of the dead over living people. People in the modern society have been liberated themselves from the dead; they should be free to make political decisions themselves. ${ }^{93}$

\section{Overcoming Cultural Legitimization of Extreme Nationalism}

It is observed that "the search for cultural identity is sometimes pursued through aggressive nationalism." Many activists claiming for repatriating the cultural property apparently dream of reverting to the golden age of their nation. Excessive nationalism, however, is dangerous because of its self-proliferating nature. Nationalism might have been necessary when the Koreans pursued independence from Japan, because it usually reinforces the loyalty and commitment of those concerned. Since their independence, however, Koreans have been using nationalism to alienate the former enemy. ${ }^{95}$ When repatriationism prevails in connection with 'mini-Sinocentrism, ${ }^{96}$ it may well serve as a vehicle to fill the people with fanatic self-esteem.

91 Constitutional patriotism conceptualizes the civic bond in a way that leads to more liberal political outcomes than liberal nationalism does, because what liberal nationalists conceive as the core object of their theory, i.e. a singular national culture, is more of an abstraction than a set of normative commitments centered on a constitution. See J.-W. Müller, Constitutional Patriotism 9 (2007).

92 J. Stinson, Greece to Britain: Hand over Artwork, USA TodAy, Apr. 1, 2008, reprinted in supra note 46, at 41-2, available at https://usatoday30.usatoday.com/news/world/2008-03-30-marbles_n.htm (last visited on Apr. 17, 2017).

93 Rhee, supra note 4, at 337. See also id. at 42 (indicating that the most foolish behavior is letting the dead standing in the way of establishing friendly relationships between living peoples).

94 Preamble to the Nara Document, supra note 48 , at 1 , 4.

95 It is said that, in the ROK, there is a lasting antipathy toward Japan, now commonly referred to as an island of 'dwarfs.' See Cumings, supra note 78, at 78.

96 Jeong-Mi Lee, Chosŏn Korea as Sojunghwa, the Small Central Civilization: Sadae Kyorin Policy and Relations with Ming/Qing China and Tokugawa Japan in the Seventeenth Century, 36 Asian Cultural Stud. 305-6 (2010) (describing that, modeled after the Chinese ' $h u a-y i$ 華夷' order, the Korean-centered world vision was established in the early seventeenth century, claiming itself as the sole remaining civilized country called 'sojunghwa,' i.e. small central civilization). 


\section{E. Promotion of Mutual Understanding of Peoples by Cultural Encounter}

As people become more conscious of the unity of human values and start to regard cultural property as public assets, ${ }^{97}$ cultural property is increasingly regarded as "the common heritage of humankind," "98 being "one of the basic elements of civilization and national culture." 99 Preamble to the Convention concerning the Protection of the World Cultural and Natural Heritage adopted on November 16, 1972, ${ }^{100}$ declares that cultural heritage "need[s] to be preserved as part of the world heritage of mankind as a whole." 101 As a Canadian court stated:

The arts and sciences are admitted amongst all civilized nations, as forming an exception to the severe rights of warfare [e.g., the right to take something as spoils of war], and as entitled to favour and protection. They are considered not as the peculium of this or of that nation, but as the property of mankind at large, and as belonging to the common interests of the whole species. ${ }^{102}$

From the perspective of such cultural internationalism, universal museums have a unique value for the human race as a whole, not just for each nation. In light of the Declaration on the Value and Importance of Universal Museums signed in December 2001 by the directors of 19 dedicated museums, ${ }^{103}$ many Japanese institutions are well qualified to fulfill the responsibility as custodians of cultural property. First, they have the top-notch expertise needed to preserve the artifacts in their collection and carry out academic research. Second, they have a wide array of cultural objects from around the world, which enable the visitors to compare them one another and fully understand the significance of each object. Third, they are open to all citizens

97 International Charter for the Conservation and Restoration of Monuments and Sites (The Venice Charter 1964), pmbl., available at https://www.icomos.org/charters/venice_e.pdf

98 See Preamble to the International Guidelines for Crime Prevention and Criminal Justice Responses with Respect to Trafficking in Cultural Property and Other Related Offences, at 2. See G.A. Res. 69/196, U.N. Doc. A/RES/69/196 (Dec. 18, 2014), available at http://www.un.org/en/ga/search/view_doc.asp?symbol=A/RES/69/196 (last visited on Apr. 17, 2017).

99 UNESCO Convention, pmbl.

1001037 U.N.T.S. 15511 , at 151.

101 The preservation of cultural heritage is "of great importance for all peoples of the world." See The Hague Convention of 1954, pmbl.

102 J. Merryman, The Marquis de Somerueles, Vice-Admiralty Court of Halifax, Nova Scotia Stewart's Vice Admiralty Reports (1813), 5 Int’L J. Cultural Prop. 319 (1996).

103 Declaration on the Value and Importance of Universal Museums, 1 ICOM NEws, 4 (2004), available at http://icom. museum/fileadmin/user_upload/pdf/ICOM_News/2004-1/ENG/p4_2004-1.pdf (last visited on Apr. 17, 2017). 
and researchers wishing to access their collection.

Even from a nationalistic viewpoint, it seems much better to part with repatriationism and create a system of cooperation between the current possessors of cultural property and the source countries. Cultural diversity constitutes "a common heritage of humanity." in various locations is an important precondition for the "life of morally serious and aesthetically delightful. ... It would be a disaster if all art stays at home."105 Cultural property overseas can be a powerful ambassador for promoting mutual understanding across the world. Expatriated Korean cultural property may call people's interest in Korea. Even if the current owner retains the ownership, there are a variety of ways to carry out the exhibition of cultural property, such as simple loans, mutual loans and the establishment of a multinational museum.

A meaningful example is the France-ROK Agreement regarding the Oegyujanggak books. In 1993, the ROK agreed to loan certain cultural property in exchange for the Oegyujanggak books. In the final Agreement of April 2011, however, France declined to take the loan of the Korean cultural property and offered a renewable loan of the Oegyujanggak books for the duration of five years. This decision was strongly criticized in France, because it would prompt the claim for unconditional repatriation of cultural property. ${ }^{106}$ Most possessors prefer mutual loans to simple loans. The Metropolitan Museum, e.g., agreed to repatriate a large wine vessel known as the Sarpedon Krater to Italy, in exchange for the long term loan of other objects. The Agreement of 1974 between the Musée Louvre and the Metropolitan Museum illustrates another possibility: they decided to reunite the head and body of a Sumerian statue and take turns to exhibit the whole artifact every four years. ${ }^{107}$ Such practice is said to signal a shift in the relationship between the museums and the source countries. ${ }^{108} \mathrm{Ye}$, another option for improving the access to cultural property is the opening of a branch museum in a source country, displaying cultural objects therefrom. Such a multinational museum provides a good example of denationalization of cultural property. ${ }^{109}$

104 Preamble to Convention on the Protection and Promotion of the Diversity of Cultural Expressions, Oct. $20,2005$. 2440 U.N.T.S. 43977 , at 311.

105 P. Bator, An Essay on the International Trade in Art, 34 STAN. L. Rev. 306 (1982).

106 See Arguments Pro and Con in France over the Loan of Oegyujanggak Books 外奎閣図書の貸与めぐりフランス国内で賛否 対立, JoONGANG DAILY (Korea) 中央日報, Nov. 21, 2010, available at http://s.japanese.joins.com/article/ 097/135097.html (last visited on Apr. 17, 2017). <available only in Japanese>

107 A. Caubet, The Historical Context of the Sumerian Discoveries, 241-242 Museum INT'L 74-5 (2009).

108 Fincham, supra note 80, at 958.

109 Siehr, supra note 20, at 1094. 


\section{Conclusion}

Cultural property should be dealt with in the framework of forward-looking cooperation, rather than that of "kako no seisan [clearing of the past]." An interesting example can be found in the 2006 exhibition of the objects excavated from Yangsan Bubuchong Tomb to which the Tokyo National Museum lent a number of precious objects. In future negotiations, Korean museums may offer the opportunity for Japanese researchers to study documents of the Government-General of Korea, of which so few have been transported to Japan. The Japanese have to recognize the sentiment of the Korean people. Such sentiment is represented by the recollection by a Korean poet, saying, while he appreciated the Japanese efforts to gather and preserve the dismembered Korean historic remains, he lamented for "national disgrace' that the continuity of the Korean ancestral history had been revealed for the first time by the Japanese people rather than their descendants. ${ }^{111}$ A key to the success in cultural cooperation must be "sensitivity to the delicate moral and cultural issues ... and to the value of a collaborative approach that helps minimize confrontation between disputing parties."112

110 An international lawyer suggests that the Japanese and the Koreans should complete the task of "kako no seisan" [clearing of the past] politically, instead of discussing the validity of the relevant treaties. See Shigeki Sakamoto, Problems of the Japan-Korea Treaties: From the Perspective of International Law 日韓間の諸条約の問題: 国際法学 の観点から, in Japan-ROK Joint History Research Committee 日韓歴史問題共同研究委員会, Report of the Japan-ROK Joint History Research Committee (First Term): Report of the Third Working Group (2005) 日韓歴史共同研究報告書 (第1期): 第3分科報告書, at 22, available at http://www.jkcf.or.jp/history_arch/first/3/01-0j_sakamoto_j.pdf (last visited on Apr. 17, 2017). <available only in Japanese> The author considers that "kako no seisan" has already been done, and that, as the titles of the agreements of 1965 indicate, the economic and cultural cooperation, based on the reflection upon lessons from history, is the task of his and future generations.

111 Nam-seon Choe, Public Lectures on Korean History 4: Introduction to the Study of Tumuli 朝鮮歴史通俗講話4: 古墳=開題 , 1:6 Dongming 東明, Oct. 8, 1922, at $11<$ available only in mixed writing of Chinese and Korean>.

112 J. Nafziger, Cultural Heritage Law: The International Regime, in The Cultural Heritage of Mankind 246-7 (J. Nafziger \& T. Scovazzi eds., 2008). 
